\title{
ORIENTACIONES BÁSICAS ACERCA DE LA ENSEÑANZA DEL DERECHO INTERNACIONAL EN CIENCIAS POLÍTICAS Y SOCIALES
}

\author{
Juan Carlos VELÁZQUEZ ELIZARRARÁS*
}

RESUMEN: La hipótesis central del autor estriba en que en la actual sociedad globalizada, el derecho internacional ha dejado ya de ser materia exclusiva de las escuelas y facultades de derecho para convertirse en un patrimonio disciplinario compartido con las ciencias políticas y sociales, particularmente con la ciencia de las relaciones internacionales. En tal virtud, es que se requiere fundamentar y desarrollar una nueva pedagogía, implementar mecanismos avanzados de su enseñanza-aprendizaje e incentivar profundas actitudes didácticas del profesor, todo ello inscrito en una reforma integral del sistema de educación superior prevaleciente y un cambio cualitativo de la concepción que se tiene de la disciplina en las universidades y centros educativos donde se imparte.

ABSTRACT: The author's central hypothesis is that in today's globalized society international law is no longer the exclusive province of law schools and law faculties but is shared with the political and social sciences and especially with the study of international relations. For that reason it is necessary to establish the basis for and develop a new form of education, to implement progressive teaching and learning methods in its delivery and to promote a deep understanding of education among teaching staff, combining all this in a comprehensive reform of the existing higher education system and a qualitative change in the way the discipline is viewed within the universities and educational centres where it is taught.

RÉSUMÉ: L'hypothèse centrale de l'auteur est que dans l'actuelle société mondialisée, le Droit International n'est plus une matière exclusive d'étude dans les Ecoles et facultés de Droit, mais est devenu un patrimoine disciplinaire partagé avec les Sciences Politiques et Sociales, particulièrement avec la Science des relations Internationales. Il lui paraît nécessaire de développer une nouvelle pédagogie, de créer des mécanismes avancés dans l'enseignement et l'apprentissage et d'avoir de nouvelles attitudes didactiques de la part des professeurs, tout cela étant possible en réformant d'une manière intégrale le système d'éducation supérieur et avec le changement qualitatif de la conception que nous avons de la discipline dans les Universités et Centres d'enseignement.

* Doctor en ciencias políticas y sociales por la UNAM. Profesor titular de carrera en la Facultad de Ciencias Políticas y Sociales de la UNAM. Profesor de derecho internacional público y privado en el Posgrado de Derecho de la UNAM, y de derecho internacional jurisdiccional, derecho comunitario y teoría general del derecho internacional público en la Maestría de Derecho de la Universidad Anáhuac del Sur. Posdoctorante en derecho internacional civil por la Universidad Complutense de Madrid. 
SUMARIO: I. Marco referencial y aproximación introductoria. II. La importancia capital de la enseñanza del derecho internacional. III. La necesaria ruptura con el dogmatismo en la enseñanza disciplinaria del derecho internacional y la conveniencia del método interactivo. IV. La percepción interdisciplinaria y el método interactivo a través del aprendizaje teórico y de la enseñanza práctica. V. La enseñanza intelectual y la enseñanza profesionalizante del derecho internacional en el ámbito universitario contemporáneo. VI. Organización de actividades educativas complementarias y la dinámica docente. VII. Las funciones de evaluación y acreditación de la disciplina del derecho internacional.

\section{MARCO REFERENCIAL Y APROXIMACIÓN INTRODUCTORIA}

El derecho internacional ha dejado ya de ser materia exclusiva de las escuelas y facultades de derecho para convertirse en patrimonio disciplinario compartido de las ciencias políticas y sociales, particularmente de las relaciones internacionales. Esta afirmación parte de una concepción moderna e integral que se fundamenta en el hecho innegable de que, por un lado, los procesos actuales de las relaciones internacionales y el fenómeno globalizador de la sociedad internacional, influyen de manera determinante en la naturaleza, noción conceptual, fundamento, técnica, objeto, contenido, extensión y diversificación de la ciencia del derecho internacional, e incluso han llegado a jugar un papel fundamental en el redimensionamiento de su función normativa y reguladora de la compleja y dinámica fenomenología del mundo que vivimos; y que, por el otro, una vez establecido, el derecho internacional ejerce acción recíproca hacia las relaciones y la política internacionales y hacia el propio proceso globalizador, y no en pocas ocasiones, ordena, atempera, limita y condiciona su comportamiento. Es esta la realidad y el reto del nuevo derecho de gentes, tal como lo vislumbramos varios iusinternacionalistas nacionales y extranjeros y que ha quedado plasmado en diversas propuestas doctrinales, debates teóricos, trabajos de la Comisión de Derecho Internacional de la ONU, así como en investigaciones de fondo, libros especializados, programas y planes de estudio de las principales universidades, academias e institutos de vanguardia de todo el orbe.

El derecho internacional puede ser estudiado y enseñado a través de distintos enfoques, entre los que destacan: el tradicional y el moderno. El 
primero supone la utilización de la perspectiva formalista para la revisión de contenidos normativos y fórmulas de prosapia eminentemente anglosajona, básicamente europea. El segundo, es de naturaleza eminentemente analítico-crítica y pretende sustentarse en una metodología científica más dinámica y abierta a los cambios para aprehender la producción y aplicación del orden jurídico emanado de una sociedad internacional en constante evolución.

Si propugnamos por la consolidación de una Escuela Mexicana de Derecho Internacional que unifique criterios y reúna voluntades y conocimientos de excelencia, y a la vez se encuadre en el mapa curricular de las ciencias políticas y sociales, debemos partir del rescate de esta ciencia jurídica para hacerla realmente equitativa y más auténtica, y que responda a intereses más genuinos como Estados en vías de desarrollo. En esta perspectiva, el estudio del derecho internacional debe ubicarse en los contextos de la actual crisis general, de la globalización y de la ramificación de sus campos de regulación, esto es, en los nuevos ámbitos jurídicos derivados, como son los siguientes: económico, social, constitucional, político, laboral, civil, monetario, financiero, corporativo, comunitario, mercantil o comercial, cooperativo, administrativo, del desarro1lo, humanitario, de los derechos humanos, cósmico o ultraterrestre, fiscal, procesal, de las comunicaciones, penal, tecnológico, de la energía y las materias primas, entre otros, y por supuesto, los más novedosos como el ambiental, el bursátil, el informático y, el de las minorías y los grupos étnicos. En suma, se trata de lo que en ciencias políticas y sociales denominamos: extensión y diversificación de la ciencia legal internacional.

Desde una perspectiva sistémica, propia de la ciencia política, el derecho internacional en su amplia connotación, es un subsistema regulador del sistema político mundial y del sistema de relaciones internacionales, que a su vez constituyen una parte inseparable de las relaciones humanas. Y dado que la sociedad internacional se desarrolla en consonancia con determinadas leyes históricas, estas leyes son definidoras asimismo de las direcciones principales de la evolución tanto del sistema político mundial y de las relaciones internacionales como del propio derecho internacional. Consecuentemente, existe una vinculación esencial entre éste y las ciencias políticas y sociales y de éstas con otras disciplinas, con las generalmente se confunden y circunscriben equivocadamente, tal es el caso de la diplomacia, la moral internacional, el protocolo y la cortesía internacionales, la política exterior y la política internacional. 
El derecho internacional llega a ser muchas veces la columna vertebral en los planes de estudios de instituciones de educación superior donde se imparte la enseñanza de las ciencias políticas y sociales, especialmente las relaciones internacionales, por ejemplo, en algunos países europeos, asiáticos y entidades de Estados Unidos de América. En otros casos, como en la Facultad de Ciencias Políticas y Sociales de la UNAM, el mapa curricular pretende ser congruente con el carácter inter y multidisciplinario de las relaciones internacionales y por ello se establece un equilibrio entre seis áreas disciplinarias básicas: teórico-metodológica, política internacional, economía internacional, derecho internacional, política exterior de México, y estudios regionales. Empero, en cualquier situación, existe consenso y un común denominador: concederle al derecho internacional un relevante papel como herramienta práctica de trabajo; un mecanismo tangible y objetivo de solución de problemas políticos, económicos, sociales y situaciones cotidianas; un poderoso instrumento que concretiza las relaciones internacionales; y un elemento de negociación útil y efectivo de la política exterior de países no hegemónicos, cuando se conoce a fondo y se tiene la voluntad de aplicarlo, lo que desafortunadamente no ocurre las más de las veces. Esta es al menos, la enseñanza histórica que se desprende de la experiencia jurídica internacional de varios Estados soberanos como el mexicano a lo largo de los últimos 150 años.

El derecho internacional debe ser estudiado y discernido con mucho mayor cuidado, dedicación y profundidad por los internacionalistas, los humanistas y los estudiosos de las ciencias políticas y sociales. Para comprender la esencia de esta importante disciplina, fundamental para el estudiante y el profesional, es necesario constatar que la creciente rapidez en los cambios y la complejidad de la problemática internacional, así como la mayor participación de México en el teatro de las relaciones internacionales, justifican en gran medida, la importancia que se ha dado en todo el mundo y en nuestro país al estudio profundo del derecho internacional y de las ciencias políticas y sociales como formas del conocimiento de la realidad de México y de otros países de América Latina, así como la de todo un conglomerado de naciones que conforman el mundo de nuestros días en sus múltiples y cambiantes procesos. Al respecto, señalaba el egregio jurista francés Michel Virally, que: "en derecho inter- 
nacional, lo único permanente es el cambio y lo único estable, la renovación constante". ${ }^{1}$

A través de la enseñanza-aprendizaje del derecho internacional a lo largo de las últimas tres décadas, hemos llegado al convencimiento de que esta tendencia ha propiciado que disciplinas como el derecho, las ciencias políticas, la sociología y las recientes como la economía y las relaciones internacionales, hayan salido de los esquemas tradicionales de referencia para el análisis de la problemática nacional y mundial, esto es, han sido desfasadas, y los marcos de análisis por ellas propuestos, se han revelado hace tiempo insuficientes; de ahí que hoy se hable de "crisis de la ciencia", "crisis de las teorías", "crisis del método", "crisis del derecho internacional", "crisis de los sistemas", etcétera. Sin embargo, el imperio de tales disciplinas no quiere ceder ante las nuevas realidades del mundo ni ante las necesidades actuales de conocimiento y de la construcción de nuevos parámetros científicos de su enseñanza y de su investigación. Y es aquí precisamente donde se explica la necesidad de ampliar, extender y diversificar el conocimiento y aplicación del derecho internacional, para aprehender, transmitir y difundir sus nuevos perfiles y ámbitos de acción.

Al respecto, afirma Alonso Gómez Robledo que si nos referimos al estado real que guarda la enseñanza del derecho internacional en numerosos países, se puede constatar que no hay una gran concordancia entre la primordial importancia que se le reconoce en las declaraciones y resoluciones de la asamblea general y lo que en realidad se aprecia en la evolución y consolidación de esta disciplina. ${ }^{2}$ En nuestra opinión no se trata

1 Virally, Michel, El devenir del derecho internacional, México, FCE, 1999, p. 495.

2 Gómez-Robledo Verduzco, Alonso, "Enseñanza del derecho internacional público", Temas selectos de derecho internacional, México, UNAM, IIJ, 1999, pp. 11 y 12, señala textualmente lo siguiente: "Las causas que están en el origen de esta situación pueden ser ciertamente de orden múltiple y variar no sólo de un país a otro, sino incluso ser diversas de una institución a otra. Algunas provienen de las dificultades para establecer debidamente los ya sobrecargados programas de la enseñanza universitaria, pero otras son más graves y se explican en parte como resultado si no de actitudes exactamente negativas, sí, por lo menos, de lo que podríamos llamar actitudes de clara indiferencia con respecto al derecho internacional. Con toda razón se ha dicho que el peso de la tradición y de lo ya consagrado no podrá jamás subestimarse; el derecho internacional público al igual que el derecho internacional privado se implantaron e impusieron en forma relativamente tardía en los programas universitarios en comparación con las disciplinas de derecho interno (civil, penal, procesal, etcétera), debiendo contentarse en las antiguas universidades y por largo tiempo, de no pasar de ser otra cosa que una materia optativa (incluso hoy en día, aunque parezca sorprendente permanece como optativa en países tales como Gran Bretaña, Canadá, India, Brasil y Japón). Este fenómeno parece haber sido muy característico entre los Estados de Europa central después de la 
precisamente de una incorporación a destiempo de la materia en los planes de estudio de educación superior, sino que en muchas universidades la enseñanza del derecho internacional ha hecho simbiosis con la joven disciplina de las relaciones internacionales, llegándose incluso a considerar - erróneamente por supuesto - que esta última podría sustituir al derecho de gentes. Y esto resulta ser un equívoco pues, como el mismo autor señala, si bien las relaciones internacionales son una ciencia heurística y analítica, esto es, de una gran utilidad para explicar, por ejemplo el proceso legislativo y normativo jurídico internacional, sus limitaciones y alcances, sin embargo, no puede, ni es su propósito, pretender ser sustitutiva de la ciencia del derecho internacional público; se trata de dos disciplinas muy diferentes, que utilizan métodos científicos por completo diversos en el análisis de sus investigaciones y en el tratamiento de los problemas objeto de estudio. Esto lo razonamos como juristas y como internacionalistas; porque tenemos las dos formaciones y estudiamos las dos vertientes científicas. Por ello es que nos pronunciamos más por la convergencia y complementariedad de ambas disciplinas que por absurdas pretensiones sustitutivas. ${ }^{3}$

Consideramos que de ninguna suerte se justifica el rechazo por nadie a las normas generales del derecho internacional. Más aún, desde la perspectiva de su enseñanza-aprendizaje en el ámbito de las ciencias políticas y sociales en países en vías de desarrollo, tal rechazo está mucho menos

Primera Guerra Mundial; a pesar del interés que se generó como consecuencia de la creación de la Sociedad de Naciones y no obstante la importancia que se le otorgaba en el seno mismo de la organización, el derecho internacional público no constituía en general materia de examen (en los llamados exámenes de Estado), y todavía a finales de la década de los treinta, el derecho internacional público seguía estrechamente vinculado a la materia de filosofía del derecho.

3 Coincidimos ampliamente con Gómez Robledo cuando señala a la letra que: "Al constituir el derecho internacional contemporáneo un obstáculo a la política del uso de la fuerza - contrariamente a lo que sucedía con el derecho internacional imperante durante el siglo pasadoel Instituto de Derecho Internacional, en su sesión de Ginebra, puso de relieve que esto mismo puede constituir una explicación de por qué varios especialistas en relaciones internacionales han adoptado, con mayor o menor rigor, una actitud negativa y casi hostil frente al derecho internacional, lo cual se pone de manifiesto por el hecho significativo de que la gran mayoría de ellos no consagra ninguna atención al desarrollo del orden jurídico internacional contemporáneo, salvo con objeto de refutarlo en forma por demás simple y breve, y sin mayor justificación conceptual. Igualmente no puede dejar de mencionarse como otra posible causa que ha contribuido a opacar la verdadera importancia del derecho internacional y ha creado menosprecio por parte de la opinión pública, el hecho de que una gran mayoría de los países del Tercer Mundo vean al derecho internacional con una gran desconfianza en razón de que dicho orden jurídico habría quedado sustancialmente estructurado y consolidado en el siglo pasado bajo la influencia preponderante, si no absoluta, de las grandes potencias coloniales". 
justificado, pues al intentarlo, éstos lo estarían debilitando y yendo en contra de sus propios intereses, a la vez que perdiendo un poderoso elemento de negociación política y económica. En un orden paralelo de reflexión, cabe preguntarnos quiénes, de qué tipo, con qué enfoques y de qué manera participan los docentes en el proceso de enseñanza-aprendizaje del derecho internacional en especialidades de las ciencias políticas y sociales. Así, tenemos que en México como en el resto de América Latina se sigue fomentando la enseñanza del derecho internacional a través de una "marcada inclinación por el examen de monumentales concepciones doctrinarias", soslayando casi por completo, y sin mayor esfuerzo heurístico-crítico, el análisis de la práctica internacional, tal y como se desprende sobre todo de los fallos, casos y precedentes sentados por los principales tribunales internacionales como la CPJI, la CIJ, la CPA de La Haya, el TPIY, el TPIR, las diversas cortes de derechos humanos, el Tridemar, incluso opiniones individuales y disidentes, laudos arbitrales políticos y comerciales, entre otros.

Es por ello que diferentes profesores e investigadores como Michel Virally, Morton A. Kaplan, Nicholas Katzenbach, Modesto Seara, Thomas Buergenthal, Diez de Velasco y especialmente el recordado maestro César Sepúlveda, entre otros de nuestra época, han manifestado en sus libros, en sus clases y conferencias que en lo general, desde hace ya varias décadas en los centros de enseñanza superior, se ha "implantado un nefasto método verbalista de trasmisión de conocimientos, impartiéndose doctrina apartada de toda realidad práctica". ${ }^{4}$

\section{LA IMPORTANCIA CAPITAL DE LA ENSEÑANZA DEL DERECHO INTERNACIONAL}

Desde la perspectiva de las ciencias políticas y sociales el derecho internacional público como sistema de normas se forma dentro de una estructura histórica precisa, se conforma en un sistema político particular y se genera en el marco específico de una sociedad determinada. Es sólo partiendo de esta concepción que podemos explicarnos cómo el derecho internacional es susceptible, ya sea de consolidar y reforzar el equilibrio

4 Sepúlveda, César, conferencia magistral "Enseñanza y actualidades del derecho internacional público", México, UNAM, Instituto de Estudios de Derecho Comparado, 12 de julio de 1984. 
de poder en la sociedad internacional, o bien moderar e incluso, en ocasiones, rectificar el libre juego de las relaciones de potencia. ${ }^{5}$

Fiel intérprete de esta realidad, ya don Antonio Gómez Robledo enfatizaba que el conocimiento $y$, por consiguiente, la enseñanza del derecho internacional dentro del espectro de la diplomacia y de las relaciones políticas internacionales es de una importancia sustancial. Si bien es cierto que puede perfectamente concebirse en teoría la negociación y redacción de un tratado o convenio internacional a nivel profesional como una cuestión de mera técnica diplomática, el problema de índole eminentemente jurídica, que se planteará inmediatamente después de concluida ésta y que será el de la interpretación misma del tratado, no podrá llevarse a cabo sin el previo y riguroso conocimiento de los principios y reglas que configuran la estructura del derecho internacional positivo. ${ }^{6}$

Jennings ha observado con razón que la enseñanza del derecho internacional es particularmente importante porque ni su contenido ni su estructura se presentan con claridad para el no iniciado. ${ }^{7}$ El iusinternacionalista debe no sólo explicar el contenido de su asignatura, sino también propagar su misma razón de ser y argumentar su adición e incorporación al orden interno. Debe insistir en la realidad de un cuerpo normativo en expansión que no es engendrado por un ente extraño, sino por la voluntad, más o menos mediatizada, del propio Estado receptor de la norma. Consecuentemente, continúa siendo muy importante insistir en la delimitación, el objeto, la delimitación, el fundamento, la conceptualización, la

5 Burton, J. W., International Relation, a General Theory, Cambridge, University Press, 1967, pp. 22 y ss.; Virally, M., "Le Juriste et la Science du Droit", Révue de Droite et Sciences Politiques (RDPSP), París, 1964, pp. 591-611.

6 Gómez Robledo no duda en concluir que el papel que se otorga a la enseñanza del derecho internacional público dentro de la amplia gama de las diversas disciplinas o materias jurídicas que se imparten en la mayoría de las universidades y facultades de derecho y de ciencias políticas, es muy limitado, dejando aún mucho que desear, quedando todavía un camino inmenso por llenar, otro tanto por rectificar y bastante por mejorar, completar y perfeccionar. La misma preocupación manifestaba don César Sepúlveda en sus cátedras.

7 Jennings, R. Y., "Teachings and Teaching in International Law". Essays in International Law in Honor of Judge Manfred Lachs. The Hague, 1984, p. 121. Jennings ha denunciado el carácter obtuso, parroquiano y oscurantista dominante, a su entender, en la doctrina iusinternacionalista y que resulta perjudicial para su consideración pública. Véase en esta dirección igualmente su trabajo "International Law and the Citizen", Mélanges M. Virally, París, 1991, pp. 341-347. 
filosofía, la historia, la naturaleza y la evolución del derecho internacional a modo de propedéutica de la disciplina. ${ }^{8}$

Hay que tener presente que en esta asignatura no se explica simplemente una rama del derecho, sino un nuevo ordenamiento jurídico. Aquí cobra actualidad la afirmación de Nippold en 1924 de que en ninguna otra parte del derecho es tan necesario como en derecho internacional liberarse de todos los prejuicios y de todas las opiniones preconcebidas. ${ }^{9}$ Es frecuente encontrar todavía profesores y alumnos que motivados por el desconocimiento y la animadversión, se convierten en nuevos "negadores" del derecho internacional, o, al menos, relativizan considerablemente su alcance y eficacia. Ante esta situación, el profesor que se considere vanguardista debe hacer énfasis en el propio desarrollo y consolidación de este ordenamiento jurídico que ha abandonado, definitivamente, el plano originario de los principios teóricos y especulativos y ha adquirido un funcionamiento regular, tangible y efectivo en sus incontables instituciones. Conforme a nuestra experiencia, en el ámbito de las ciencias políticas y sociales, la mayoría de los estudiantes perciben con facilidad el argumento sencillo e irrebatible de la interdependencia entre los Estados que conduce inexorablemente a la tendencia progresiva del jus gentium. Como lo asienta Javier Roldán Barbero, estamos convencidos de cuanto más se profundice en el derecho internacional más se constata y se valora su incidencia en las relaciones internas y en las relaciones internacionales. ${ }^{10}$

8 Siempre hemos pensado que un buen curso de derecho internacional público debe partir de una unidad temática introductoria precisa, abarcando todos estos aspectos; una especie de marco histórico-conceptual con un objetivo educacional central: conocer las bases históricas y teórico-metodológicas del derecho internacional público, para comprender su relación con las ciencias políticas y sociales y la noción de un nuevo orden jurídico internacional. Algunos de los temas que debe incluir son: visión historiográfica y elementos básicos de la teoría general del derecho internacional; derecho internacional: sistema particular de derecho; conceptualización; derecho internacional público y derecho internacional privado; objeto; fundamento, contenido y técnica; derecho natural y derecho positivo; el derecho, la equidad y la justicia; el ius cogens internacional; derecho internacional general, regional y local; derecho internacional y derecho interno; el dualismo, el monismo y las tesis coordinadoras; relación y vinculación del derecho internacional con las ciencias políticas y sociales; crisis y renovación del derecho internacional actual; retos y realidad del nuevo orden jurídico internacional. El orden de presentación de los subtemas puede variar de acuerdo al criterio del docente y el nivel del grupo.

9 Nippold, O., "Le développement historique du droit intertional depuisle Congrés de Vienne", Recueill des Tours de l'Académie de La Haye, 1924, p. 5

10 Javier Roldán Barbero es un reconocido catedrático de derecho internacional público y relaciones internacionales de la Universidad de Almería, con quien coincidimos in extenso, amén de que tenemos formación muy parecida. Recomendamos ampliamente su libro: Ensayo sobre el 
En estos últimos años hemos advertido que en diferentes países europeos como Francia, Italia, Alemania, España y el Reino Unido, por ejemplo, es cada vez más frecuente que las asignaturas derivadas del derecho interno adviertan y anticipen contenidos internacionales, fundamentalmente del derecho comunitario europeo pero no siempre con precisión, alimentando una conciencia y una sensibilidad por la política exterior y la acción diplomática de este grupo de países. Lo cierto es que a la labor de fomentar la enseñanza del derecho internacional público se han aplicado tradicionalmente diversos organismos en la convicción de que así se promueve de mejor manera la concordia y la cooperación entre los pueblos y las personas, y se reviste de seguridad jurídica unas relaciones internacionales cada vez más profusas y dinamizantes. Esta labor de amplia promoción encuentra su explicación en el hecho de que en numerosos Estados, principalmente de América Latina, África, Asia y Oceanía, aún no es obligatorio cursar la asignatura de derecho internacional para obtener la licenciatura de derecho. Para nosotros la ruta a seguir es clara pues nos anima la convicción de que el tiempo corre, en general, a favor de la internacionalización de las relaciones políticas y sociales y, por consiguiente, a favor de la revalorización académica y pública de nuestra disciplina.

derecho internacional público, Universidad de Almería, 1996, 158 pp. Especialmente consúltese su sección 3a. "La enseñanza", pp. 125-155. Por su interés, citamos a la letra un párrafo inscrito en la p. 128: "Este afianzamiento del ordenamiento internacional puede explicar que en ciertos manuales de la asignatura se hayan aligerado los temas destinados a introducir al lector en los fundamentos conceptuales, históricos y doctrinales. Por mi parte, soy partidario de recalcar, pero no de recargar de erudición, los planteamientos iniciales en detrimento del estudio del derecho internacional positivo contemporáneo, entre otras razones, porque esos planteamientos básicos deben acompañar la explicación de la materia a lo largo de todo el curso académico. Así, todo el temario debe conducir a entender la peculiar juridicidad del Derecho de Gentes, del mismo modo que las consideraciones históricas deben salir a relucir a propósito de cada institución internacional en concreto". Otro autor que comparte experiencias semejantes derivadas de su amplia carrera de 40 años en la docencia e investigación del derecho internacional, es el profesor Modesto Seara Vázquez quien, por cierto, combina su formación de publicista del derecho de gentes y especialista en relaciones internacionales. 


\section{LA NECESARIA RUPTURA CON EL DOGMATISMO \\ EN LA ENSEÑANZA DISCIPLINARIA DEL DERECHO INTERNACIONAL Y LA CONVENIENCIA DEL MÉTODO INTERACTIVO}

En los tiempos de la actual globalidad resulta cada vez más inviable entender la significación y alcance real del derecho internacional, particularmente en ciencias políticas y sociales, si no se resalta prioritariamente dentro del proceso de su enseñanza-aprendizaje la praxis internacional, judicial, arbitral, política o diplomática, en la que se desarrolla concretamente el orden jurídico positivo. El método interactivo, en sus dos vertientes indisociables profesor-alumno y teoría-práctica, previene del riesgo de caer innecesariamente en dogmatismos o en retórica infundada que no crean sino falsas apreciaciones, o en el mejor de los casos solamente producen riesgosas generalizaciones acerca de la sociedad internacional y de la política mundial y que no encuentran mínima cabida en cualquier esfuerzo analítico o de aproximación científica.

El método jurídico comparado útil en derecho internacional y el método interdisciplinario arrogado por las relaciones internacionales deben guardar, como premisa, correspondencia con el concepto dinámico, amplio e incluyente que tenemos de la disciplina, concepto cuyos rasgos básicos hemos venido señalando en esta y otras investigaciones ampliamente difundidas y convalidadas. Sobre el particular, también en la impartición académica de la asignatura debe subrayarse la necesidad de delimitar con la mayor precisión posible los espacios respectivos de la lex lata y de la lex ferenda, esto es, las funciones cognoscitiva y valorati$v a$ del fenómeno jurídico. Asimismo, debe resaltarse en este ámbito nuestra convicción de la improcedencia de sustentar planteamientos formalistas y dogmáticos para el conocimiento del derecho de gentes.

Esta postura comporta algunas dificultades en la enseñanza de la materia. En efecto, la complejidad del derecho internacional obliga inexorablemente a simplificar las explicaciones que se dan en el aula de una realidad compleja marcada en muchos ángulos por un incierto grado de normatividad, por la dispersión de las fuentes, por los límites de la codificación, por los inacabados debates doctrinales, por la politización de las posturas de publicistas y privatistas, por las irreductibles posturas de los delegados de las entidades soberanas, por las dudas que encierra el proceso consuetudinario, por la escasa recepción del derecho convencional en los órdenes jurídicos internos de los Estados; o bien, por la estrechez 
de pronunciamientos jurisdiccionales. Y ante esta situación llega a parecernos más cómodo y aparentemente más "claro" y "didáctico", como lo intuye Roldán Barbero, aferrarse a un texto escrito, preferentemente único, y así tomar como reglas de referencia un proyecto de artículos de la Comisión de Derecho Internacional (CDI) para explicar la responsabilidad internacional, convenios codificadores apenas aceptados para hablar de la sucesión de Estados, disposiciones de soft law en relación con el derecho internacional del desarrollo, instituciones en franca experimentación para explicitar el derecho comunitario o el de la integración o el corporativo, y hasta resoluciones doctrinales como las aprobadas por el Instituto para la Unificación del Derecho Privado (Unidroit) o la Uncitral en distintas materias (como las que contempla el derecho internacional privado).

Sabemos bien que la enseñanza consiste esencialmente en una operación selectiva de conocimientos, inexcusable ante el ensanchamiento vertiginoso del derecho internacional material. Verbigracia, el derecho intencional marítimo, el aéreo o el espacial, por su carácter técnico y casuístico, están especialmente llamados a una simplificación radical de su normativa; o también la costumbre, en razón de su naturaleza intrincada y controvertida. Para nosotros los profesores, las explicaciones transmitidas en el desarrollo de los cursos ordinarios entrañan indefectiblemente una represión acusada de nuestro saber; $\mathrm{y}$, sin embargo, hemos de adaptarnos a las circunstancias y no perder de vista la perspectiva pedagógica, la cual tiene sus propias exigencias, límites y alcances. En todo caso, consideramos que la ampliación de conocimientos no debe emplearse en abigarrar o tecnificar excesivamente la disertación, sino justamente en ordenarla e ilustrarla mejor. ${ }^{11} \mathrm{Y}$ aquí el método interacti-

11 Javier Roldán cita al iusinternacionalista español J. A. Pastor Ridruejo, que lo ha precisado así: "Es cierto que hay que formar e informar a los alumnos de la licenciatura con rigor en las ideas y con riqueza en los datos, pero creo que no se les debe de abrumar en ningún caso con planteamientos científicos propios de niveles superiores". Y agrega Roldán: "A mi entender, la inevitable simplificación y la sopesada selección no deben llevar aparejada, empero, una mixtificación del derecho. La persecución de la simetría en la alocución, del encuadre perfecto, de la pulcritud del razonamiento, conduce muchas veces a deformar una realidad jurídica mucho más dúctil, más controvertida, más polifacética, impidiendo la aseveración de verdades incontestables. La advertencia, al menos, de esos contornos escarpados es una actitud más honesta, que refugiarse en un discurso altamente tecnificado $\mathrm{y}$, si es posible, bien nutrido de documentos y citas bibliográficas que puede con su efecto de aturdimiento del que lo recibe, o confundirlo y hacerlo dudar de la seriedad de su preocupación, o, lo que es más fácil, hacerle comprender que sólo cuando domine todo el aparato técnico estará en disposición de hacerse preguntas "trascendentales"”. 
vo-comparativo nos muestra otra de sus bondades: también escudriñando en el interior del derecho internacional positivo, el discurso puede hacerse menos brillante y el aprendizaje más arduo, pero sólo así logramos aproximamos a la esencia del fenómeno normativo. Es cierto que no tiene mucho sentido ahondar en el aula en las controversias doctrinales, pero no se deben ignorar por completo los debates y las disidencias, porque, primero, ponen de manifiesto que el derecho no es geométrico y, segundo, fomentan un espíritu crítico, dialéctico, mediante la confrontación de tesis discrepantes. En derecho y en ciencias político-sociales el alumno debe aprender a interactuar y a comparar.

En el campo de las ciencias políticas y sociales el conocimiento del derecho internacional debe ser dimensionado y transmitido con criterios más amplios, más flexibles y más abiertos a la pluri e interdisciplinariedad. De esta suerte, el internacionalista participa en la misión que incumbe a cada disciplina del plan de estudio de la licenciatura, en particular las relaciones internacionales, consistente en enseñar a "problematizar" el derecho, la de ejercitar al alumno en la técnica jurídica, técnica que no se ciñe, por definición, a una hermenéutica. El derecho internacional es en sentido preciso un terreno privilegiado para el adiestramiento en el razonamiento jurídico. Se trata, en definitiva, no sólo de transmitir un cúmulo de nociones (aspecto informativo de la enseñanza), sino también de inculcar unas habilidades jurídicas (aspecto formativo de la enseñanza). Esto lo explicaba J. Balmes hace medio siglo al afirmar que la enseñanza tiene dos propósitos, el primero, instruir a los alumnos en los elementos de la ciencia; segundo, desarrollar sus habilidades y talentos para que al egresar de los centros de estudio puedan realizar los adelantos proporcionados a su capacidad. O como también lo han indicado los maestros italianos P. Barcellona y G. Cotturi, se debe comunicar simultáneamente una información sobre el derecho y una actitud hacia el derecho internacional.

Se debe insistir en que todo este entramado docente va interrelacionado: al descifrar en todas sus vertientes el derecho positivo se coopera en el perfeccionamiento de la técnica, la terminología y el razonamiento jurídicos, y, consiguientemente, se contribuye a formar una óptica panorámica sobre el fenómeno legal internacional, y se logra afianzar una sensibilidad particularmente objetiva sobre la fenomenología social y política internacional donde éste se inscribe y proyecta. En todo este proceso de aprendizaje no debe pasarse por alto la formación y visión personal 
del profesor, lo que condiciona el descubrimiento de la norma, cuyo proceso de gestación o renovación no siempre está dilucidado. El criterio varía según se trate de un docente "puro" del derecho internacional de formación estrictamente jurídica y un docente "impuro" del derecho de gentes de formación internacionalista. Y se quiera o no, cada realidad formativa mediatiza, a fortiori, la aprehensión-exposición de los conocimientos y, más aún, su valoración. Como correctivo a esta irreductible subjetividad del docente de derecho internacional, dentro y fuera de las ciencias políticas y sociales, se debe enfatizar, una vez más, la honestidad científica, el rigor en el análisis y la relativización, por principio, de presuntos axiomas.

\section{LA PERCEPCIÓN INTERDISCIPLINARIA Y EL MÉTODO INTERACTIVO A TRAVÉS DEL APRENDIZAJE TEÓRICO Y DE LA ENSEÑANZA PRÁCTICA}

Entre otras ventajas, la enseñanza interactiva del derecho internacional permite, particularmente en ciencias políticas y sociales, no sólo la interacción sistemática y permanente entre profesor y alumno, sino la apertura interdisciplinaria y la interrelación balanceada entre el aprendizaje teórico y la enseñanza práctica de la disciplina. Así, entendemos que interdisciplina, teoría y práctica se ubican en un mismo nivel de importancia, esto es, que la base del aprendizaje teórico no debe ser descuidado ni menos abandonado, pues como bien lo ha reiterado el profesor universitario Héctor Fix-Zamudio, la visión unidisciplinaria siempre tiene limitaciones riesgosas y una práctica que esté desvinculada de la doctrina no puede traducirse sino en una serie de datos pragmáticos carentes de toda sistematización. ${ }^{12}$ Y como también lo enfatiza Alonso Gómez Robledo, en nuestros espacios académicos, en nuestras facultades de derecho y aun de ciencias políticas y sociales, ha sido bastante fuerte el peso de la enseñanza unidisciplinaria y meramente teórica, cargada de un método de tipo discursivo y verbalista, en casi todas las materias jurídicas, especialmente quizá en mayor medida dentro del derecho internacional público. Por ello, hoy tienden a proliferar las opiniones de los publicistas que se

12 Fix-Zamudio, Héctor, "Algunas reflexiones sobre la enseñanza del derecho en México y Latinoamérica", Anuario Jurídico VI, UNAM, Instituto de Investigaciones Jurídicas, 1979, pp. 159-175. 
pronuncian porque se intente desde una óptica global poner un mayor énfasis en la instrucción de tipo práctico. Aunque debemos aclarar que esta apreciación no es compartida por los privatistas o especialistas en derecho internacional privado, quienes le atribuyen a esta disciplina, y no les falta razón, un carácter eminentemente instrumental y práctico, con un contenido cada vez menos teórico, empero de doctrina aún muy enfrentada y debatida. A fin de cuentas, consideramos que una cuestión destaca sobre las demás: con mucha frecuencia la serie de especulaciones simplistas y ficticias que se formulan sin ningún fundamento real, ocultan el verdadero carácter y espíritu del derecho internacional, y son precisamente resultado de la ausencia de una enseñanza sistemática de la práctica internacional, esto es, del derecho internacional positivo.

En este orden de ideas, el método interactivo, que promueve dinámicamente el vínculo profesor-alumno, presenta una interesante alternativa al método tradicional (presencial) de impartición de clase de tipo catedrático o magistral. Este tipo de enseñanza, que en lo general es el que continúa utilizándose en nuestras facultades y escuelas de derecho y de ciencias políticas y sociales, ha tenido como resultado que se produzca una casi total y absoluta pasividad por parte del alumno, convirtiéndolo en un agente receptor en esencia, nunca actor. Por ello, no dudamos en que la vieja técnica didáctica emisor-receptor del conocimiento debe ser superada a través de métodos de enseñanza y aprendizaje que posibiliten una participación real y más directa del estudiante de derecho internacional, no sólo en el campo del derecho sino también en el de las relaciones internacionales. ${ }^{13}$ La lección catedrática del derecho internacional debe pues, ser trascendida.

13 Por estas razones, Alonso Gómez Robledo ("Enseñanza del derecho...", cit., nota 2, pp. 15 y 16) señala a la letra: "no podemos estar de acuerdo con parte de las conclusiones a que se llegó el año pasado en el Segundo Seminario sobre la Enseñanza de Derecho Internacional, en Bogotá, bajo los auspicios de la Organización de Estados Americanos. En el informe final sobre metodología se afirma que el empleo de la clase magistral utilizada en las facultades de derecho de América Latina sigue siendo considerada como muy conveniente, ya que por lo demás un buen número de obstáculos de tipo material hacen que cualquier otro tipo de enseñanza sea realmente imposible de implantar o instrumentar. Por nuestra parte, pensamos que siendo indiscutible y evidente que la existencia de problemas tales como la demanda masiva de enseñanza o la escasez de recursos bibliográficos puedan hacer muy difícil la implantación de otra serie de técnicas de enseñanza, esto no implica en modo alguno que no se pueda y no se deba, cada vez más y aun dentro de este tipo de limitaciones, intentar, ensayar, tratar de algún modo que se establezca, cada vez más, una mayor participación por parte del alumno". 
Por otra parte, consideremos que desde siempre el derecho internacional ha sido comparado con el derecho interno, confrontación que resulta desventajosa para el primero como ordenamiento menos evolucionado. Tal afirmación es cierta si el comparativo se establece con los Estados de derecho avanzados de nuestra época, no con otras sociedades que se desenvuelven en la anomia. Ya en el aula, de cara al alumno, es importante marcar diferencias entre el sistema internacional y el derecho interno (mexicano, en nuestro caso), pero igualmente insistir en la interpenetración de los dos órdenes; postura ésta hoy promovida por las llamadas 'tesis coordinadoras', que no precisamente eclécticas. No olvidemos que hay un fondo normativo común al derecho internacional y al derecho interno y a la vez un aporte que aquél efectúa a la formación jurídica general. Como ha indicado P. M. Dupuy, en su reconocida obra Droit internacional public, para apreciar los principios generales del derecho introducidos en el derecho internacional hay que orientarse por el derecho comparado. Para tal objetivo, el iusinternacionalista debe manejar con soltura los fundamentos legales del Estado, tanto de derecho público como de derecho privado (ya sea este último internacional o interno). Recordemos que la técnica del derecho privado conviene al derecho internacional público, pues este último es, en realidad, básicamente, también un derecho de coordinación.

El derecho internacional y el interno guardan estrecha relación y convergencia, por lo cual tenemos que actualmente las investigaciones de los internacionalistas aparecen en primer lugar por haber dispuesto el terreno y forjado el método de toda investigación que tenga por objeto las relaciones entre ordenamientos jurídicos distintos, públicos y privados, internos e internacionales, o inclusive interestatales. En muchos casos también el estudio del derecho interno sirve para conocer la adecuación nacional al derecho internacional, de la misma manera que para México reviste sumo interés conocer la normativa emanada del TLCAN o de la Unión Europea - socios comerciales prioritarios- en relación a temas internacionales que resultan influidos por un medio regional más ambicioso jurídicamente como el que hoy predomina en el viejo continente. 
Por otra parte, como lo hemos defendido en diferentes foros,,${ }^{14}$ el estudio del derecho internacional material desemboca de modo ineluctable en los dominios de otras asignaturas jurídicas y no jurídicas como las ciencias políticas y sociales, y las relaciones internacionales. Inversamente, estas y otras materias han de beber en las fuentes del derecho internacional para comprender y completar su reglamentación. Esta idea se corrobora, en especial, en lo relativo al derecho comunitario europeo, cuyo vasto ámbito de competencias lo convierte en objeto de estudio para prácticamente todas las disciplinas de las licenciaturas en derecho y ciencias políticas, y lo sustrae de pretensiones acaparadoras. De esta suerte, al profesor de derecho internacional público le interesa conocer las bases de otras asignaturas, el momento y las líneas generales de su impartición, lo que conduce al necesario conocimiento cabal de los planes de estudio de derecho y de ciencias políticas y sociales y al recomendable intercambio de pareceres y experiencias con colegas de facultades, institutos y centros de estudio afines, sobre el tratamiento que cada especialidad y área del conocimiento conceden a las numerosas instituciones y figuras de un derecho como el internacional tan amplio y complejo, característico del mundo global de nuestros días en sus múltiples y cambiantes procesos.

Más allá del contacto con otras materias de la licenciatura de relaciones internacionales, la enseñanza apropiada del derecho internacional comporta también, según lo reitera nuestra experiencia, adoptar una perspectiva interdisciplinaria que desborde la esfera estrictamente jurídica para adentrarse en el contexto histórico, en el medio socioeconómico, en el sistema político nacional y mundial, en la política exterior, en la estructura de poder, tal como fue postulado al inicio de este capítulo. El profesor debe, pues, desterrar un 'rancio' positivismo como el que el especialista E. D. Brown apreció y denunció hace apenas dos décadas en la docencia del derecho internacional en el Reino Unido. ${ }^{15}$ En Francia, en cambio, esta metodología pedagógica está más difundida. Dutheil de la Rochére, comentando este método, señala que, con esta apertura didácti-

14 Para mayor referencia consúltese nuestro texto: Nuevos desarrollos temáticos para el estudio del derecho internacional público, México, UNAM, FCPyS, 2004, especialmente el capítulo 4. El derecho comunitario europeo, del profesor Alejandro Chanona Burguete, pp. 211-248.

15 Brown, E. D., "The Teaching of International Law in the United Kingdom", en Cheng, B. (ed.), International Law. Teaching and Practice. London, 1982, p. 174. 
ca, lo que se pierde en técnica jurídica se adquiere en perspectiva. ${ }^{16} \mathrm{Al}$ igual que lo percibe Roldán Barbero, a nuestro juicio, esta aproximación a otras ciencias sociales y a las políticas no debe entrañar una desatención hacia el razonamiento jurídico y el derecho positivo, entre otras consideraciones porque dicho acercamiento no deforma la dimensión normativa, sino que ayuda a aprehenderla. No debe entenderse esta perspectiva interdisciplinaria de la enseñanza como la infiltración en las explicaciones del salón de clase de un agregado de datos extraños al fenómeno jurídico internacional, sino como un elemento inseparablemente unido a la regla de derecho internacional.

Al hermanar el derecho con su contexto político y social se muestra que hay una lectura jurídica de tantos hechos internacionales relevantes que pueblan los medios de comunicación, aunque esta lectura sea, en ocasiones, confusa, fragmentaria, marginada o incluso abiertamente contravenida. A nuestro entender, no deben faltar en un buen curso de derecho internacional interpretaciones jurídicas de los casos y situaciones más significativos y actuales de la sociedad y la política internacionales, abriendo incluso una especie de apartado que, por ejemplo, bajo la modalidad de Seminario interactivo abordamos en la Facultad de Ciencias Políticas y Sociales de la UNAM en México, con la denominación de Relaciones jurídicas internacionales, donde no se dejan de advertir y en su caso revisar, las implicaciones o condiciones de índole política, económica y social que toda relación jurídica internacional conlleva.

Es casi seguro que muchos alumnos precisan solamente de algunos fundamentos históricos y conceptuales sobre determinados conflictos internacionales que les resultan incomprensibles para, a partir de tales premisas, desarrollar por cuenta propia en adelante un conocimiento más riguroso. De esta manera, se facilita la comprensión del proceso jurídico-internacional en íntima conexión con el medio en que se gesta y desarrolla y, además, se puede lograr algo adicional que acostumbramos anteponer al comienzo y al final de un curso de derecho internacional o de relaciones jurídicas internacionales: inculcar en el estudiante un sentido interés por la política internacional. Con esta idea, no hacemos sino

16 Dutheil de la Rochére, J., "The Teaching of Public International Law in France", en Cheng, B. (ed.), International..., cit., nota anterior, p. 184. En cuanto a los Estados Unidos de América, se ha escrito que "While the British approach is quite positivistic, rule-oriented and formally descriptive, the American approach tends to be more process-oriented and contextual", Nafziger, J. A. R, "Teaching Public International Law in the United States", Archiv des Völkerrechts, Londres, 1986, p. 216. 
convalidar las afinidades irrefutables que entrelazan al especialista en relaciones internacionales con el iusinternacionalista, este último también plenamente capacitado para hacer funciones analíticas y heurísticas de la dinámica internacional actual desde su perspectiva genuina, 'prescriptiva' y primordialmente jurídica. ${ }^{17}$

No debiera pensarse que con estas propuestas dirigidas al estudiante, se busca defender una politización excesiva o demasiado influenciada por la formación jurídico-política de quien esto escribe, sino como una forma vehemente de estimular una conciencia crítica que se extienda al escenario internacional, cada vez más próximo e influyente, sensibilizando al alumno en estos temas e instruyéndolo para que pueda participar en activo con argumentos fundados en el campo profesional y operativo, así como en los grandes debates y discusiones de esta era global. Quizás en esto meditaba el egregio profesor español, recientemente fallecido, Antonio Truyol y Serra cuando escribía en 1957 que "la significación de la enseñanza del derecho internacional rebasa la de una transmisión de conocimientos técnicos". ${ }^{18}$ También cabría reflexionar dentro de esta línea argumental, una tesis mantenida por O. Kimminich, autor alemán que, aun advirtiendo la conveniencia de adoptar un método docente pluridisciplinario, observaba con tino que el iusinternacionalista contribuye a subestimar la importancia de su asignatura al persuadir a sus estudiantes de la necesidad de valorar la norma a la luz de la ciencia política y de la política internacional. ${ }^{19}$

$Y$ es que se trata, en clara actitud antidogmática de su enseñanza en el aula, de no pasar por alto, ocultar o menos aún, ignorar las deficiencias estructurales del derecho de gentes, o sus inconsistencias y contradicciones, éstas derivadas de la naturaleza de sus propias fuentes doctrinales, para hacer más "atractiva" la materia para el común de los estudiantes. Suavizar los defectos, encubrirlos, no es la mejor manera de combatir la

17 Javier Roldán Barbero cita para ejemplificar esta afirmación a H. S. Quicgley, cuando afirmó que: "International law without international relations has no root; International relations without international law have no fruit", en varios autores, Proceedings of the Second Conference of Teachers of International Law and Related Subjects, Washington, 1926. Aunque recientemente A. Pellet ha argumentado esta interacción que no debe, empero, conducir a que ambas disciplinas se fundan en un magma indistinto.

18 Truyol y Serra, Antonio, "Notas sobre el derecho internacional público como disciplina científica y materia docente", Revista Española de Derecho Internacional, Madrid, 1957, p. 444. También id., La sociedad internacional, Alianza Editorial, 1979.

19 Truyol y Serra, "Notas sobre el derecho...", cit., nota anterior, p. 441, cita al autor O. Kimminich. 
incredulidad del aprendiz acerca del valor y la firmeza, la autonomía y la efectividad del derecho internacional. Entendamos que, sin duda, sólo un ignorante del derecho internacional puede pretender 'desjuridificar' las relaciones internacionales. Se trata ante todo de captar y transmitir el saber de la disciplina con realismo y objetividad, no con un planteamiento rectilíneo y enclaustrado del ordenamiento internacional, porque entonces no se estaría enseñando el derecho internacional de nuestros días: se explicaría un orden utópico, ficticio, concebido parcialmente en el ánimo del docente. En este sentido, le sobra razón a Roldán Barbero cuando afirma que el iusinternacionalista gana en autoridad científica y popular a medida que su campo de estudio se expande y no tiene por qué sofisticar el estado de las relaciones políticas y sociales internacionales de la contemporaneidad.

El alumno debe ser conducido a distinguir lo que son insuficiencias objetivas del medio internacional, de lo que pueden ser críticas subjetivas a sus normas sin llegar a descalificar, por principio, la existencia de una comunidad internacional de derecho. Esto es realmente fundamental. Decía Paulo Freyre en ese su extraordinario libro Pedagogía del oprimido que el docente, como opera prima, debe infundir en el alumno una conciencia crítica, analítica y centrada, que no sumisa ni pasiva ni pragmática, sino desalienante para que, como componente de la sociedad civil, se pronuncie sobre un ordenamiento tradicionalmente reservado a los Estados a través de sus responsables políticos; esto es, se trata de articular otra manera de defender que la educación no tenga necesariamente que contribuir a perpetuar el orden social y político preestablecido. ${ }^{20}$

\section{LA ENSEÑANZA INTELECTUAL Y LA ENSEÑANZA \\ PROFESIONALIZANTE DEL DERECHO INTERNACIONAL EN EL ÁMBITO UNIVERSITARIO CONTEMPORÁNEO}

En distintas y prestigiadas universidades que conocemos directamente como la Universidad Nacional Autónoma de México, la Complutense de Madrid, la Libre de Berlín, la de París X-Nanterre, o incluso la de Texas en Austin, donde se imparte la disciplina de derecho internacional en su amplio espectro, junto con otras asignaturas inscritas en ejes del cono- 
cimiento de las ciencias políticas y sociales, se plantea actualmente una interrogante que pareciera corresponder más al campo de la filosofía del derecho internacional que al de la administración de su enseñanza y su instrumentación pedagógica. La cuestión apunta a la necesidad de discernir, con estricto criterio académico y una concepción funcional-operativa, si la ciencia del derecho internacional debe ser mejor instruida en un ambiente universitario o tecnológico para definir su orientación principal, bien sea esta profesionalizante o de corte intelectual, o bien de línea sincrética. Y la respuesta no es sencilla porque, en efecto, se apela al modelo educativo prevaleciente en un tiempo y un espacio determinados, a una realidad histórica y social concreta y, más directamente, al tipo de modelo de universidad a que se aspira.

Al respecto, Roldán Barbero acota una autocrítica, una serie de hechos inobjetables de los que los docentes del derecho internacional somos testigos y protagonistas, que acaso sólo comentamos y que no nos atrevemos a denunciar y combatir por simple comodidad y conformismo. Lo cual también advierte Agustín Basave Fernández. ${ }^{21}$ Nos referimos a que es corriente escuchar o leer que la Universidad ha perdido vitalidad y protagonismo social por desatender las demandas provenientes del mercado de trabajo; que muchos alumnos aseguran no ver claramente la utilidad de lo que estudian; que en relación específicamente al derecho internacional, algunos estudiantes comentan, en ocasiones, que la asignatura les interesa, pero que no creen que sea práctica para sus actividades profesionales futuras; 22 que el derecho internacional en España, como ocurre en México pero no en Francia, es marginado o ignorado en el temario de la inmensa mayoría de las oposiciones (en la FCPyS de la UNAM la última plaza abierta a concurso de oposición en esta materia la ganó quien esto escribe hace más de 25 años).

En suma, este cuestionamiento encierra un particular interés, dado que derecho se considera generalmente como una carrera práctica, con salida profesional, y no como enseñanza meramente cognitiva. Hoy sabe-

21 Basave Fernández del Valle, Agustín, Filosofía del derecho internacional. Iusfilosofia y politosofia de la sociedad mundial, México, UNAM, IIJ, 1989, pp. 15-36.

22 En España es alto el interés que despierta entre los alumnos el estudio del derecho internacional, lo cual viene avalado por el siguiente dato: este país suministra el mayor contingente de inscritos en los cursos de la Academia de Derecho Internacional de La Haya (en 1994, 107 españoles entre los 628 participantes). Cabría preguntarse, para el caso de México, cuál es el grado de interés mostrado hacia esta importante disciplina. El dato de que disponemos muestra que en 1998 solamente había nueve mexicanos inscritos en esa academia de vanguardia mundial. 
mos que la universidad debe ser formativa y acercarse a la realidad social y profesional del entorno en que se inscribe, de suerte que, sin abandonar las irrenunciables tareas de transmitir la ciencia y realizar investigación, logre, a través de una oferta coherente de titulaciones académicas, dar respuesta a las nuevas demandas del mercado laboral. Al señalar que la mayoría de los alumnos sólo requiere pequeñas dosis de derecho internacional y no más, el profesor español Adolfo Miaja de la Muela de inmediato aclaraba que la universidad es algo más que una escuela profesional: es una fuente de cultura. Este tipo de razonamientos deben ser revisados a la luz de la consolidación de la disciplina y, en particular, de la proliferación de compromisos jurídicos-internacionales contraídos por México y la mayoría de los países a consecuencia de su abrupta apertura exterior en aras de la globalidad. En este sentido, no hay duda de que cuanto más implicado esté un Estado en el plano internacional, más importancia cobra el derecho internacional, público y privado. Pero es cierto también que algunos juristas tienden a omitir en su profesión las consideraciones jurídico-internacionales que encierran sus asuntos no porque no vengan al caso, sino sencillamente porque las desconocen al haber circunscrito su campo de conocimiento al ámbito propiamente interno. Esto le ocurre a la gran mayoría de los licenciados en derecho y litigantes en América Latina, y sucede justamente cuando la expansión del derecho internacional penetra en la esfera material de cualquier rama del derecho interno, de la ciencia política y de las ciencias sociales.

Por consiguiente, la importancia de la enseñanza del derecho internacional se encuentra ya en el plano técnico-jurídico. Aunque todavía un buen número de sus normas no son objeto de valoración o aplicación por el "operador jurídico" (como se le denomina ahora) en su ejercicio profesional, no cabe de ninguna suerte asumir que muchos ámbitos normativos del ordenamiento internacional son inútiles para el jurista y, por consiguiente, para el sociólogo, el administrador público, el comunicólogo o el politólogo. A esta nueva fenomenología del derecho internacional también la identificamos como la irrupción de los técnicos y 'tecnificación' de la materia y de los procedimientos. Ello ocurre así porque uno de los efectos más notables de la transformación de las relaciones internacionales en el derecho internacional, es el acrecentamiento de los bienes jurídicos a tutelar. Existe actualmente una creciente diversidad de materias reguladas en centenares de convenciones internacionales, en las que se pueden afectar las leyes de sociedades mercantiles, transacciones 
petroleras, prevención y represión de actos ilícitos, solución de controversias, derechos de autor o de patentes. Pueden regular los contratos colectivos de trabajo, prácticas comerciales restrictivas, delitos contra la comunicación o el medio ambiente, infracciones de cuello blanco o la protección de inversiones privadas extranjeras, así como las transferencias de valores, tecnología, invisibles y servicios, entre muchos otros temas de la actualidad internacional.

Muchas de las cuestiones así reglamentadas son de la incumbencia de especialistas en otros campos del derecho o de las ciencias políticas y sociales, o de científicos y técnicos a quienes por lo general no interesa el derecho internacional público o privado. Por esta razón, sería muy riesgoso dejar enteramente estas materias en manos de los peritos en sociedades mercantiles, en penalizaciones e infracciones, en derecho procesal o jurisdiccional, cooperación judicial o en derechos de autor y considerarlas fuera del dominio de los juristas y de los iusinternacionalistas. Y en el proceso concreto de la regulación en estos campos y otros ámbitos novedosos, sería también muy riesgoso pretender dejar en manos de los técnicos la formulación de la ley, pues el técnico o el tecnólogo, y por derivación el tecnócrata, carecen por lo general de criterio jurídico y político. Consecuentemente, debe haber concurrencia entre internacionalistas, especialistas y técnicos cuando el asunto a tratar así lo amerite, pero en una adecuada división de responsabilidades. En otros términos, cuando cualquier materia es objeto de alguna convención internacional o de un convenio entre Estados $\mathrm{u}$ otros sujetos extranacionales, adquiere por ese solo hecho significación, tanto desde el punto de vista del derecho internacional como del de la especialidad de que se trate.

Por otro lado, vale la pena reflexionar sobre el hecho de que no en todos los centros de educación superior nacionales y extranjeros, el programa de derecho internacional, tal como está configurado ordinariamente, corresponde a la concepción de la universidad como servicio público dispuesto a los intereses generales de toda la comunidad nacional y de sus respectivas comunidades autónomas. En varios casos los objetivos educacionales parecen ir dirigidos a ciertos sectores de la sociedad y a los intereses de determinadas clases y necesidades sociales, cuando lo que debe buscarse es la inserción integral de la sociedad como un todo en la obtención y operación del conocimiento internacional. Es cierto que no puede ignorarse que el mercado de trabajo cada vez demanda más empleados con una formación general, y que las humanidades y las cien- 
cias sociales no son un complemento, sino una base. No olvidemos que la universidad es algo más que una fábrica de producción de títulos especializados. Más que un terreno de preparación de futuros empleos debe representar además de todo eso, como lo advertía el pedagogo C. García Gual, una conciencia crítica, una posición analítica, reflexiva y propositiva del hombre ante su entorno. Por su parte, el carácter insensible y precario del mercado laboral y la inminencia de los exámenes - a los cuales se habitúa el alumno a lo largo de toda su formación como un método 'natural' de 'selección por cosificación'- propenden a estrechar el análisis y a fomentar precisamente, el utilitarismo del alumno. Y esto es un grave error porque la universidad no debe sólo adiestrar para un oficio, sino también completar la educación de la personalidad.

En esta línea argumentativa, el derecho internacional favorece un saludable espíritu cosmopolita, una identidad post-nacional que está en el sentido primordial e idealista de la propia universidad y que constituye una ampliación del horizonte intelectual insoslayable para el siglo XXI que apenas comienza. Por tal razón, su enseñanza en ciencias políticas y sociales dentro de una universidad intelectual-profesionalizante y de alto compromiso social como lo es la UNAM, invita a reflexionar sobre la presencia y desarrollo del derecho de gentes en tres dimensiones precisas: internacional, transnacional y supranacional; amén de que las propias relaciones internacionales lo son hoy también, paralela e incluyentemente, transnacionales y supranacionales. Y ello es así porque:

a) La sociedad internacional se manifiesta por el sistema tradicional de relaciones diplomáticas interestatales, incluyendo las relaciones entre Estados y organismos internacionales y entre las propias organizaciones intergubernamentales, que son relaciones de representación y coexistencia.

b) La sociedad transnacional viene a quedar caracterizada por el volumen y alcances que va teniendo cada vez más la cooperación internacional en cuestiones de interés común. El concepto de 'sociedad transnacional' corresponde en términos generales al de 'derecho transnacional' que ha sido desarrollado por reconocidos iusinternacionalistas mexicanos y del exterior. En este nivel, los principales sujetos siguen siendo los Estados y hasta cierto punto las organizaciones internacionales, pero muchas de estas relaciones transnacionales se realizan y fomentan mediante grupos semipúblicos o privados que tratan directamente entre sí, o con entes públicos. Las actividades que llevan a cabo estas fuerzas transna- 
cionales $^{23}$ abarcan la totalidad de las relaciones culturales, jurídicas, científicas, políticas y económicas, y hay casos en que tienen funciones de control económico que les vienen a dar, según expresión de Karl Renner, 'facultades delegadas de mando'. Sea cual fuere su importancia, el hecho es que las relaciones transnacionales representan un objeto significativo de ordenamiento y regulación del derecho internacional en la sociedad actual.

c) La sociedad supranacional se identifica porque en ella las actividades y funciones de los Estados y agrupaciones están mezcladas en instituciones internacionales, que aunque su condición legal deriva de tratados internacionales y llevan a cabo sus funciones gracias al acuerdo político y a las contribuciones económicas de los Estados miembros, realizan propósitos y tareas particulares y toman decisiones propias y, a medida que cobran más firmeza, prácticamente se emancipan de los Estados o grupos que las constituyeron y desarrollan una personalidad, una autonomía y un poder con caracteres exclusivos. Es indudable que la existencia y amplitud que adquieren a diario las relaciones supranacionales en un mundo cada vez más global, influyen y determinan la estructura de un verdadero derecho supranacional. Para ejemplo baste señalar el nivel de alta supranacionalidad que tienen los sistemas jurídicos, legislativos y normativos emanados de la Unión Europea, el FMI, el Banco Mundial, la ISO, la OMC, la OCDE y algunos organismos especializados del sistema de Naciones Unidas, entre los principales. ${ }^{24}$

Para cerrar este apartado, admitamos que actualmente la educación debe ser concebida como un proceso social de amplio espectro, abierto, tolerante y, ante todo, 'humanizante' y 'culturizante'. En esta línea con-

23 Véase Merle, Marcel, Sociología de las relaciones internacionales, Alianza Editorial, 1986, pp. 335- 396. Este autor nos plantea desde la perspectiva de la sociología histórica un interesante estudio sobre las denominadas fuerzas transnacionales, a saber: Las Organizaciones No Gubernamentales (ONG), las firmas multinacionales y la opinión pública internacional (OPI).

24 Velázquez Elizarrarás, Juan Carlos, "La organización internacional como subdisciplina, subsistema y paradigma de las relaciones internacionales contemporáneas. Aproximaciones teóricas, interdisciplinariedad y reestructuración general", Relaciones Internacionales, México, UNAM, FCPyS, núm. 68, 1995, pp. 27 y 28. “El 'supranacionalismo' es también un fenómeno histórico asociado muchas veces al grado de desarrollo de los Estados. No es sólo una figura jurídica, ya que este aspecto queda cubierto por la formalidad constitucional y la personalidad detentada, sino un agente activo dentro del fenómeno del poder en la organización internacional; es un elemento endógeno de ésta que le da capacidad para ejercer una autoridad indiscutible e imponer políticas y decisiones obligatorias para los Estados... El poder mundial, la cooperación y el conflicto son constantes históricas que determinan la naturaleza, contenido y madurez de la maquinaria política de la organización internacional y por tanto, su grado de supranacionalidad". 
ceptual, ha señalado Roberto Mesa con razón que "Universidad y política no pueden nunca separarse. No sólo se educa para la ciencia y el saber; también, fundamentalmente, para la democracia y la fraternidad". ${ }^{25}$ Fuera de toda retórica, el desarrollo de la educación es el principal fundamento del progreso de la ciencia y de la técnica, es condición de bienestar social y prosperidad material, y es soporte de las libertades individuales. Y una educación moderna ha de comprender indefectiblemente una formación en los parámetros internacionales. En suma, no dudamos en reconocer que el jurista, el sociólogo, el politólogo o el comunicólogo deben ser, ante todo, humanistas, a cuyo fin el derecho internacional colabora eficazmente. Su formación en un espacio cada vez más global y dentro de este tipo de universidad intelectual-profesionalizante que estamos construyendo particularmente en México, así lo sugiere y proyecta.

\section{ORGANIZACIÓN DE ACTIVIDADES EDUCATIVAS COMPLEMENTARIAS Y LA DINÁMICA DOCENTE}

La internacionalización de la vida política, económica y jurídica, muy acusada en México a partir de la ruptura de la 'cortina de nopal', ha provocado una importante demanda de actos públicos internacionales, lo que ha de entenderse como una actividad educativa complementaria que debe ser desarrollada a fondo. Regularmente estos eventos extracurriculares ofrecen la ventaja de permitir construcciones más creativas. Una de las cuestiones cruciales que plantea la enseñanza es la complementariedad de las explicaciones orales con los manuales y las guías didácticas - éstas sumamente útiles en sistemas de universidad abierta y educación a distancia-, los cuales ofrecen un apoyo indispensable al presentar un discurso jurídico mejor articulado, asentado y documentado. El profesor debe tener un conocimiento bastante cabal de los libros y fuentes de información que recomienda para relacionarlas con su disertación. Pero, ante todo, el docente debe esforzarse por infundir un interés propio y adicional a sus clases, procurando que las mismas no sirvan sólo para engrosar con apuntes la materia, sino también que la explicación sea entendida y razonada durante su transcurso. Evidentemente, hay unidades y temas, 
como los de inicio del programa, que se prestan más a una concepción personal que otros, como el derecho de los tratados, objeto de una codificación ampliamente aceptada, en los cuales son mayores las coincidencias con cualquier libro de texto. Por el contrario, ciertas lecciones o puntos temáticos resultan, ciertamente, más difíciles de sistematizar que otros. Entre estos últimas destacan los temas de la parte especial del derecho internacional privado o también del derecho internacional económico o los relativos al régimen internacional de sanciones en la dimensión pública, cuyos contenidos son susceptibles de presentar marcadas diferencias doctrinales.

Otro problema que obliga a ser cautos y realistas es la corta duración de los cursos 'semestrales' (de cuatro meses a lo sumo), sin descontar los imponderables y las clases muertas. Surge entonces el dilema de cuál es el ritmo que se les debe imprimir. Así, imponer una pauta acelerada a la explicación con la intención de desarrollar exhaustivamente todos los temas, puede atosigar y confundir al alumno, deslucir la explicación, perjudicar el debate, decayendo el feliz logro de los objetivos académicos propuestos. Sobre algunos temas se precisan, pero bastan al mismo tiempo, nociones básicas y bien recalcadas que puedan perdurar en la cultura jurídico-político-social del educando. Se debe procurar una adecuada planificación para que la remisión eventual de temas a los textos básicos no obedezca exclusivamente a razones de apremio. Al respecto, recalca Roldán Barbero que "la brevedad relativa del curso y la oportunidad de consulta de un manual realzan el valor de inculcar en clase, como ya hemos sostenido, un espíritu crítico, una inquietud intelectual, un talante científico, la dignidad del trabajo riguroso". ${ }^{26}$

En este orden de ideas, una cuestión fundamental también lo constituye la búsqueda por el docente del engarce, la vertebración, el hilo conductor, la relación permanente de las distintas lecciones, reiterando, anticipando, recapitulando, induciendo las respuestas del alumno, todo para conferir unidad y consistencia al programa y a la asignatura del derecho internacional. Es interesante, pues, 'hipotetizar' junto con el alumno, esto es, pensar en un supuesto de hecho real con muchas ramificaciones

26 Ibidem, p. 149. Agrega también que, en general, el profesor debe procurar, con su ejemplo, hacer una modesta contribución a la credibilidad del sistema universitario. Que su experiencia le indica que el profesor que realiza una exposición brillante por su estructura, su claridad, su amenidad, por la formulación de problemas, puede conseguir un efecto sobre el auditorio que va más allá de la comprensión de la materia. 
y exponer las normas que le son aplicables y, eventualmente, el procedimiento de arreglo de la controversia, la modalidad de reparación empleada, la imposición de contramedidas. Y es que en realidad no existe la "pureza estructural" de un programa, siendo necesario habilitar sesiones especiales de clase o espacios exclusivos para la especulación dirigida, para conjeturar y relativizar algunas cuestiones, sacudiéndolas de su nicho de inmovilidad y rigidez, despojándolas de los rasgos presuntamente lineales y dogmáticos con que pueden aparecer en el temario.

Basar en un texto único un curso que de suyo es dinámico y cambiante, es un error diametral. La comparación de autores y posturas es fundamental, junto con la prosodia, la soltura en la exposición, la claridad en las disertaciones; ello a fin de transmitir amenidad y no rutina ni desidia al receptor del conocimiento para mantenerlo motivado, participativo y despierto. No es sano escucharse indefinidamente a sí mismo. Nos debe preocupar y ocupar el indagar acerca de la verdadera receptividad del mensaje en el alumno, o sea, simplemente, saber comunicar. Y en esta tarea pedagógica, el estudiante de ciencias políticas y sociales, en especial el futuro internacionalista, por su inquietud y apertura, resulta ser un buen cómplice. Tampoco se debe ignorar la utilidad y pertinencia de la técnica del ejemplo: la multiplicación de ejemplos al objeto de ilustrar el tema, retener la atención del alumno y restar abstracción al derecho internacional. Con un análisis puramente conceptual, muchos estudiantes dormitan, se abstraen, no llegan a hacerse una idea clara de los diferentes contenidos y desarrollos temáticos. Claro está, no se trata empero de renunciar al rigor y a la precisión, cualidades éstas muy apreciadas en un jurista y en un iusinternacionalista, para el que la capacidad de expresión oral y escrita constituye una herramienta indispensable. Conforme a nuestra experiencia y la transmitida por los grandes maestros de la disciplina, el aula de clase debe ser un lugar para una reflexión más serena, para un análisis más ordenado. Por eso, consideramos insustituible la ayuda de un programa actualizado y muy bien elaborado, además de un guión personal para dotar a la disertación de una estructura y un ritmo apropiados.

El programa es un instrumento insustituible que nunca debe faltar en un curso de derecho internacional. Lo ideal es, una vez actualizado y enriquecido, facilitarlo al alumno desde la primera sesión del semestre, para comentarlo, desagregarlo, explicarlo, invitando al educando a leerlo en voz alta y abriendo espacios breves para la reflexión compartida. Es 
aconsejable solicitarle al inicio al alumno una crítica escrita al mismo, calificarla y devolvérsela al final del curso para que realice una autoevaluación y pueda así, él mismo, comparar su avance real en la comprensión de la disciplina. Además, en su elaboración, el programa debe corresponder, dentro de lo posible, a las más novedosas propuestas pedagógicas, debiendo contener por lo mínimo los siguientes elementos: datos generales de la asignatura; ubicación de la materia en el plan de estudio (asignaturas antecedentes, simultáneas y subsecuentes); marco referencial; objetivos generales; unidades temáticas, con contenido bien desagregado, y sus objetivos educacionales; instrumentación didáctica, incluyendo los mecanismos básicos de aprendizaje y los métodos de acreditación y evaluación; y, finalmente, la bibliografía, hemerografía y 'ciberografía', básicas y complementaria, amén de las fuentes legislativas, convencionales y documentales que todo iusinternacionlista requiere conocer y manejar.

La formación docente debe inspirarse en pautas y técnicas didácticas. El profesor debe, en consecuencia, pensar incesantemente e instruirse en los métodos pedagógicos. Pero estamos convencidos que la mayor parte de las virtudes del enseñante dependen del conocimiento de la materia, de la consideración hacia el alumno y de la vocación docente. Asimismo, no debe faltar por su cabal importancia la preparación permanente de las clases sin desembocar en la rutina, fácilmente perceptible e interiorizada por el alumno. La consabida masificación de la enseñanza tan común en universidades como la UNAM o la Complutense de Madrid, no es una eximente para no repensar la función docente, en especial al impartir el derecho internacional en ciencias políticas y sociales. No basta con afirmar que "el que enseña, aprende dos veces", sino que cada vez se debe enseñar y aprender mejor. En disciplinas como la nuestra, junto con las relaciones internacionales, de tanta exigencia y dinamismo, cuanto más se sepa más se gana en seguridad, en capacidad de síntesis, en motivación. Saber enseñar el derecho es saber contagiar la esencia de su conocimiento para formar en el estudiante un afianzado criterio jurídico. El conocimiento enciclopedista que antes era enteramente exigible al jurista y al internacionalista ha quedado atrás hace tiempo. El criterio jurídico es la verdadera herramienta que permite encontrar la respuesta de derecho internacional a lo que se ignora en el hecho social y político internacional e incluso nacional. Además, la actualización del libro de texto, que por razones obvias no puede estar siempre puntualmente al día, constitu- 
ye indiscutiblemente un valor añadido de la clase, un referente de consulta, pero nunca un fundamento único de la cátedra de derecho internacional. ${ }^{27}$

La enseñanza de esta disciplina debe discurrir con ritmo, con pausa, con fluidez, no venciendo con el peso del argumento sino convenciendo con la sencillez del conocimiento cierto, la armonía y el respeto al interlocutor. De esto estamos enteramente convencidos. Decía Alberto Einstein que: "Lo peor es educar por métodos basados en el temor, la fuerza, la autoridad, porque se destruyen la sinceridad y la confianza y sólo se consigue una falsa sumisión". A menudo, los estudiantes de derecho internacional, más en facultades de derecho que de ciencias políticas y sociales por cierto, se quejan de que las clases consistan en un rígido y continuo discurso magistral, excesivamente impositivo y teorizante. Pensamos que en el fondo lo que tratan de demandar es una universidad más profesionalizada que adiestre en habilidades jurídicas prácticas que les faciliten su incursión en el campo internacional operativo. Pero, en nuestra opinión, las denostadas lecciones y conferencias magistrales, siguen siendo necesarias pero no de manera exclusiva sino balanceada, combinada con otras técnicas; por ejemplo, con el método de 'Case Law' o estudio de caso, sobre el cual también se ha llegado a decir que no es apropiado para países de tradición jurídica doctrinal del 'Civil Law'. Al respecto, en un reciente estudio se asegura que esa modalidad docente, la casuística, "aunque continúa siendo una técnica fundamental para la enseñanza del derecho en los Estados Unidos, está en franco retroceso". ${ }^{28}$ Nosotros no lo vemos de esa manera. Sin caer en un pretendido conservadurismo metodológico, estimamos que para impartir un curso de derecho internacional en México, en una Facultad de Ciencias Políticas y Sociales, no se puede cifrar la enseñanza en un diálogo permanente entre profesor y alumno, en una suerte de mayéutica socrática. Conforme a nuestra modesta experiencia, las técnicas vanguardistas son más preconizadas que cultivadas. En las asignaturas optativas contempladas por los nuevos pla-

27 En este punto de reflexión, Roldán Barbero señala que "se debe aspirar a ganar confianza y dominio en la alocución, sin perder, como digo, interés por la docencia; antes al contrario, se debe avivar y renovar la ilusión académica (lo que no siempre resulta sencillo). La materia se debe no sólo enseñar, sino también contagiar; es decir, transmitir un volumen de conocimientos y, a la par, infundir vocación al alumno. Sólo preservando la propia vocación se puede comunicar interés al estudiante. Sin autocrítica, con arrogancia y suficiencia, no hay progreso personal posible".

28 Montaña Mora, M., "Harvard y la enseñanza del derecho en los Estados Unidos", Cuadernos jurídicos, Madrid, mayo de 1993, p. 24 
nes de estudio se podrá ser algo más innovador, pero creemos que siempre es conveniente transmitir un discurso hilvanado, un argumento central correctamente vertebrado, una disertación docta y secuencial.

Otra arista de la cuestión es que el profesor debe cerrar en lo posible la brecha que separa al teórico del derecho internacional de quienes están encargados de su aplicación. Para ello, el iusinternacionalista debe fomentar una formación objetiva y comunicar una información "aterrizada"; pero, por supuesto, sin pretender avalar jurídicamente toda conducta o declaración proveniente de la política exterior del país o de la política internacional, sino identificar y dilucidar la dicotomía que siempre existirá entre derecho, equidad y justicia, entre juridicidad y efectividad, entre legalidad y legitimidad. Y en este ejercicio dialéctico, no se trata de avalar la desconexión entre teoría y praxis. No es congruente dogmatizar en clases teóricas y explicitar las interrogantes y contradicciones en las prácticas. Una forma bastante adecuada de transmitir la teoría en derecho internacional es servirse de casos, preferentemente jurisdiccionales, comentar las incógnitas jurídicas que suscitan y hacer intervenir a los alumnos para recabar su parecer jurídico sobre una cuestión, aportar nuevos criterios de calificación, involucrarlos en la explicación y obtener una señal del entendimiento de la misma. Aunque el tiempo de un curso, como ya se advirtió, es corto, debe buscarse un espacio para el desarrollo sistemático de clases prácticas, vinculadas a las teóricas, convergentes temáticamente en el tiempo y con constantes referencias que las entrelacen. Los casos deben ser pocos, cuidadosamente elegidos con base en la técnica de 'estructura significativa', porque el factor tiempo es una seria limitante, y con una pluralidad de problemas jurídicos en presencia.

Refirámonos ahora a otra modalidad educativa que es el 'Seminario Interactivo', especialmente en el área de derecho internacional. En nuestra percepción, aquél puede ser utilizado en la fase terminal de la licenciatura, en la maestría y, por supuesto, en el nivel de doctorado, con excelentes resultados. Muchas tesis - alrededor de cien- de las que hemos dirigido en las dos últimas décadas, fueron producidas por alumnos seminaristas inscritos en el seminario de relaciones jurídicas internacionales, impartido en octavo semestre de la Licenciatura en Relaciones Internacionales. Su eficiencia radica en que funciona para grupos pequeños y relativamente amplios - hasta 30 alumnos - y su objetivo central es fomentar el desarrollo y la especialización de la técnica investigadora, amén de que no tiene una dimensión exclusivamente docente. Su apro- 
piado desarrollo exige una buena preparación de los temas por parte de todos los participantes, no sólo del ponente. Este método debe incentivar, dentro de las dotes fundamentalmente investigadoras y también expositivas, la lectura sosegada y crítica más especializada, la manifestación del pensamiento por vía oral y escrita, la apertura por el alumno de los temas programados o coyunturales para discusión grupal y la confrontación de las ideas; todas ellas, funciones muy provechosas para sociedades como las de nuestra América Latina, en transición democrática y cada vez más pensantes.

Por otra parte, vale la pena esbozar algunas ideas en torno a esa variable esencial de la educación interactiva del derecho internacional que es la relación profesor-alumno. De entrada, en este vínculo los sujetos activos no son cosas sino personas; el profesor no es un objeto que habla y transmite, ni el alumno es una banca o pupitre donde se colocan cuadernos de apuntes, frases o libros. Se trata, ontológicamente, de una relación en estricto humana que, cierto es, tiene particularidades pero ninguna de ellas desvirtúa el hecho de que la educación y el respeto recíproco deban ser los pilares fundamentales. Además, las reglas de comportamiento deben ser siempre las mismas, unívocas, no casuísticas. Una imagen de severidad o de autoridad no resulta apropiada si no se compensa ampliamente por la práctica de la objetividad y la imparcialidad. Es evidente que la función profesoral confiere una potestad que no debe ser abusada para imponer reglas irrespetuosas. Profesor y alumno son dos entidades que intercambian roles y tareas en convivencia dialéctica, nunca en términos de enfrentamiento o corporativismo. Por el contrario, profesor y alumno se necesitan mutuamente para preservar la confianza en una disciplina normativo-ética como el derecho internacional y en el propio sistema universitario. La relación profesor-alumno cobra su mayor logro y cuota de sentido académico cuando busca, sobre todo, estimular intelectualmente al alumno porque ello revierte necesariamente en un enriquecimiento propio. Nunca se debe olvidar que en los alumnos nuestra Alma Mater cobra vida propia. Por su propia seguridad intelectual, el profesor debe mantener siempre la misma sencillez con que define idóneamente su actitud ante la complejidad de todo conocimiento. Y al asumirse como las labores propias de un simple sembrador de semillas, las funciones docentes sólo pueden enriquecer la formación personal, nunca distraerla. No es apropiado, entonces, desplazar la atención al alumno simplemente porque no reporte incentivos económicos, remuneración 
mercantil o méritos para el currículo, reconocimientos especiales, estímulos académicos o primas para el desempeño docente y los sistemas nacionales de investigación.

En un orden argumentativo paralelo, coincidimos con quienes advierten que la figura de las tutorías debe ser amplia y permanentemente atendida; en particular, en sistemas de enseñanza escolarizada de licenciatura y posgrado, en virtud de que en las modalidades 'abierta' y 'a distancia', la instancia tutorial resulta imprescindible. La tutoría afianza el vínculo profesor-alumno, abre una posibilidad estimable de diálogo con el estudiante y de profundización en temas insuficientemente desarrollados en clase, aliviando de esta manera el peso de la masificación. Al respecto, como lo repetía incesantemente Enrique Ruiz García - excelente profesor hispano-mexicano que tuvimos en la UNAM en 1970-1973-, son los "sectores callados" el verdadero centro de atención dentro y fuera del aula, a cuyo efecto el sistema tutorial permanente suele ser la mejor solución. Y es que las relaciones profesor-alumno deben aludir a una vertiente menos optimista, si tomamos en cuenta que la comunicación con la totalidad de los alumnos es, y sería, imposible, entre otras razones por la propia masificación, por esa cada vez mayor presencia de los "sectores callados", porque proliferan el ausentismo, la apatía hacia el estudio y la irregularidad de los alumnos en todos sentidos.

El profesor debe ser al mismo tiempo, maestro y tutor, porque siempre será importante, dentro de lo posible, indagar las causas del bajo rendimiento de un alumno o incluso, de una generación de alumnos como suele ocurrir hoy con mayor frecuencia que antes. Y en esta jornada, la cosificación de la enseñanza y la falta de incentivos al docente constituyen un obstáculo real. Pensemos en que el estudiante no sólo puede estar ausente de clase físicamente, sino que también puede estar abstraído mentalmente por problemas quizás de mayor relevancia para él en esos momentos que el derecho internacional o la ciencia política y social. Entonces, captar y atender este tipo de situaciones es muy necesario y para ello, no basta saber mucho, ser docto en la materia, sino tener verdadera vocación docente, esto es, espíritu de servicio, lo cual justamente no abunda en esta era de globalidad y de flaqueza axiológica en la enseñanza. A fin de cuentas estas y otras debilidades del modelo educativo prevaleciente muestra que, sin duda, tanto profesor como alumno requieren sentirse alentados y correspondidos por el sistema para lograr su mejor desempeño. 


\section{LAS FUNCIONES DE EVALUACIÓN Y ACREDITACIÓN DE LA DISCIPLINA DEL DERECHO INTERNACIONAL}

Un profesor universitario puede tener a su cargo, especialmente en fases más avanzadas de su trayectoria, diversas actividades calificadoras: exámenes profesionales, sínodos de lectura y revisión de tesis, exámenes de grado, comisiones dictaminadoras de ingreso y promoción, comités evaluadores para estímulos o ingreso a sistemas de investigación, entre otras. Es evidente pues, que se trata de funciones importantes que deben ejercerse con sentido de responsabilidad, contribuyendo a su dignificación, en la certeza de que en ello va también la credibilidad del sistema universitario y de que en torno a esas pruebas se concitan muchas expectativas personales, en ocasiones legítimas y fundadas. No obstante, la labor evaluadora natural y ordinaria del profesor se concentra en los estudiantes de la licenciatura $\mathrm{y}$, en menor medida, de la maestría y del doctorado.

Al hilo de la postura que venimos exponiendo, no cabe duda que el carácter antidogmático que se pretende para el estudio del derecho internacional debe trasladarse a la hora de evaluar el aprovechamiento que, a nuestro modo de ver, no debe darse a través de un examen del tipo tradicional u ortodoxo. Reducir la calificación del conocimiento adquirido por un alumno a uno o varios exámenes no dice mucho, más bien muy poco; primero, porque con el examen se apela más a la asimilación mecánica y a la memorización previa a la prueba - lo que generalmente deriva en el olvido parcial o casi total de lo memorizado-, que a la medición consistente y sistemática del nivel de aprehensión; y, segundo, porque se empaña la percepción del justo rango de comprensión del conocimiento requerido. Debe reconocerse al efecto, que en esquemas masificados de enseñanza el examen, principalmente el escrito, es ideal para salir del paso, trabajar rápido en grupo, a modo de evitar la evaluación personalizada y oral, y ahorrar tiempo; empero, está demostrado conforme a la moderna pedagogía que el instrumento es relativamente absurdo y poco objetivo. Es preferible, entonces, preparar al alumno para que aprenda a ser ordenado, distribuido y disciplinado, a lo largo de todo el curso, sin intermitencias ni resultados cíclicos ni aciertos ocasionales; encausarlo didácticamente para discernir, analizar, opinar, investigar, exponer, criticar, reseñar, cuestionar, interrogarse, en suma, para interactuar sistemáticamente durante el curso, y no predisponerlo para presentar 
exámenes ponderativos de su rendimiento en una fase terminal de preguntas de contenido anunciado. Por ello, y muchas otras razones más, en esta época global, los exámenes no garantizan la calidad educativa ni exhiben fehacientemente las capacidades reales de los educandos; en especial, los exámenes extraordinarios han devenido, por cierto, en una puerta falsa, una salida fácil y aun tramposa que, desafortunadamente, muchos alumnos aprovechan con frecuencia de las deficiencias del sistema, utilizándola como última opción para acreditar la materia y - esto es lo más grave-, sin haberla cursado nunca de manera ordinaria ni en el tiempo ni en la ubicación disciplinaria propuesta por el programa y el plan de estudio. Huelga añadir que esta es una manera más de dar al traste con los objetivos y metas planteados por cualquier reforma de planes y programas educativos.

Por su parte, ya sabemos que en la ciencia del derecho internacional existe un ancho campo susceptible de valoraciones discrepantes. En tal situación, debe pedirse explicaciones adicionales. Ambas argumentaciones, pensamos, deben ser expuestas en clase y luego ser exigidas en una evaluación final oral, no en un examen escrito rígido, si lo que se pretende es una respuesta óptima. Es importante, en este caso, bajo esta modalidad evaluatoria, interrogar al alumno e interrogarse junto con él, induciéndolo para encontrar la contestación más correcta. Es cierto que la mayoría de los alumnos prefieren verdades taxativas, pero donde no las hay no se debe fingir que existen. Tampoco se puede consentir cualquier divagación del estudiante sólo porque el tema es controvertido o de debate doctrinal como es común en nuestra disciplina. Obviamente, no se trata, en ningún caso, de disimular o consentir la ignorancia. Todas estas consideraciones dan idea de ciertas dificultades aparejadas a la tarea de enjuiciar en un examen de derecho internacional, donde no todos los temas ni todos los institutos jurídicos son del todo claros y convalidados.

Antes de decidir examinar bajo una técnica ortodoxa al alumno, hay que reconocer que el temario de la asignatura, comprimido en un solo 'minicurso', es consustancialmente largo y complejo y que en él se entremezclan, por ejemplo, instituciones heterogéneas prácticamente homónimas. Como lo reitera Roldán Barbero, es de suyo estéril, y quizás contraproducente, memorizar una retahíla de órganos y de funciones si no se alcanza una visión global, crítica y profunda de la materia de que se trate. Esto es aún más cierto al enseñar derecho internacional en terrenos de las ciencias políticas y sociales, y de las relaciones internacionales. Nor- 
malmente, el 'bosque' tiene la misma o mayor importancia que los 'árboles'. También entendemos que no se debe ser muy meticuloso cuando el derecho positivo sobre una figura jurídica no es diáfano ni consistente. En cambio, sí nos parece inadmisible, a efectos de valoración, que un alumno, amparado en apuntes o manuales pretéritos, desarrolle un tema a través de una reglamentación ya reformada si en clase se explicó debida y oportunamente el nuevo derecho en vigor. En nuestra experiencia, esta infortunada desactualización, muchas veces involuntaria, se presenta con mayor frecuencia en cursos de derecho internacional privado que de derecho internacional público.

En este sentido, hay que reconocer que para poner la calificación de "aprobado" no se puede ser muy purista en el razonamiento y la terminología jurídicos, aunque se debe procurar la superación cualitativa de la asignatura. En ocasiones, cuando se es sistemático, hay que confesar que nos asaltan dudas irresolubles sobre si el alumno ha traspasado o no el umbral razonable que permite aprobar la disciplina. Por el contrario, creemos que las calificaciones honoríficas han de ser apreciadas, exigiendo para su concesión conocimientos claros, sólidos, bien estructurados y expuestos de forma correcta. Ahora bien, si lo que se trata es de transmitir al alumno de derecho internacional, además de conocimientos de calidad, la conveniencia de estudiar con regularidad durante el curso académico y no sólo en fechas críticas, necesariamente debe hacerse una clara distinción entre los mecanismos de acreditación y la evaluación propiamente dicha. A nuestro entender, la acreditación consiste en la calificación de una serie de indicadores objetivos que en su conjunto expresarán la consistencia y el nivel de aprovechamiento del alumno y su valor variará según el criterio didácticamente fundamentado del profesor titular de la cátedra. Dichos factores de acreditación serían grosso modo los siguientes:

- Lectura y crítica al programa de la materia.

- Proyecto de investigación (se mide la capacidad para proyectar investigaciones; nivel metodológico).

- Realización de una investigación semestral (tesina) escrita, para su réplica oral.

- Participación en una práctica de campo y al menos en dos actividades extracurriculares. 
- Elaboración de diferentes trabajos de opinión (sintéticos y analíticos) sobre temas selectos, tomados del programa o de hechos de coyuntura.

- Elaboración de tres reseñas bibliográficas críticas (autores selectos) (una comparativa).

- Asistencia regular a las sesiones (manifestación presencial).

- Participación constante y juiciosa en el curso.

- Exposición por escrito de uno o dos temas del programa (los elige el alumno, no se asignan por el profesor, aunque puede orientar la elección).

- Exposición oral de los anteriores temas (no se permite leer los escritos; el expositor usa tarjeta guía y conduce la discusión; se califica el manejo de público, en este caso el grupo reunido en clase ordinaria).

- Criterio jurídico, capacidad analítica y originalidad en los planteamientos.

- Formulación de un trabajo especial y uno complementario (por ejemplo un glosario de términos jurídicos usuales en relaciones internacionales).

- Criterio del profesor adjunto de la cátedra sobre el rendimiento general del alumno.

- Evaluación final oral (variará en función del rendimiento personal de cada alumno; se hace una sumatoria de todos los indicadores, se le plantean preguntas de criterio y se valoran respuestas; se le hacen señalamientos y recomendaciones directas y personales sobre su desempeño; finalmente, se le informa sobre su nota final, a la cual puede renunciar para mejorarla, bajo su riesgo, a través de un examen general de conocimientos básicos de la asignatura).

- No se realizarán exámenes parciales tradicionales, salvo que el desempeño grupal lo amerite.

Por lo que concierne a la evaluación, ésta tiene el carácter de una autovaloración grupal, esto es, se realizará con la presencia de todo el grupo y se ejecutará conjuntamente entre alumnos y profesor, buscando todos los elementos posibles para analizar la coherencia interna del programa con el plan de estudios que lo generó, con la epistemología propia de las disciplinas del derecho y de las relaciones internacionales, 
y la coherencia externa del plan de estudios con las necesidades sociales a las que intenta dar respuesta.

Antes de finalizar estas orientaciones sobre la enseñanza del derecho internacional en ciencias políticas y sociales, conviene plantear algunas ideas adicionales sobre este binomio evaluación-acreditación. Por ejemplo, concebimos al examen oral, aún con las limitaciones de tiempo y del sistema imperante, como un espacio de reflexión adecuado que permite, por de pronto, mayor transparencia y control recíprocos entre profesor y alumno; además, incentiva la oratoria, virtud apreciable en un jurista, y facilita modular mejor la nota y el tipo de preguntas, discerniendo la pura memoria de la comprensión adecuada. ${ }^{29}$

Resulta asimismo interesante plantear al alumno cuestiones importantes, implícitas y explícitas en el programa; cuestiones más agudas que busquen escrutar su capacidad de relación y permitan identificar a los más aventajados, pero no con la idea de "reprobar" a los que no reaccionan por incapacidad o por falta de agilidad en esos momentos. Más que en la pregunta sorpresiva habría que insistir en las cuestiones más significativas "para fomentar su estudio y recordatorio, propagando la sensación de que se trata de conocimientos indispensables". ${ }^{30} \mathrm{Y}$ en el proceso de ponderación tampoco debiera soslayarse la necesidad de inculcar en el educando otra cualidad importante del jurista y del iusinternacionalista,

29 José Harb Karám, un reconocido maestro universitario mexicano (ya fallecido) que nos introdujo al estudio del derecho internacional allá por 1970 y que practicaba sólo exámenes orales, nos decía que había que vencer el inconveniente del nerviosismo que puede traicionar al alumno; pero que el profesor debía ser intuitivo y tolerante para distinguir el estado de nervios del estado de ignorancia. Como lo ratifica Roldán Barbero, quien comparte la anterior idea, el examen oral ofrece, adicionalmente, una información clarificadora sobre los mecanismos selectivos de la memoria y sobre la comprensión general del derecho internacional, proporcionando datos muy valiosos para la autocrítica del docente. Efectivamente, el profesor puede reflexionar sobre las causas por las cuales algunas ideas expresadas en clase son retenidas por casi todos los alumnos y otras ideas por casi nadie. Estos puntos finos del proceso pueden ser apreciados de manera objetiva, precisamente a través de la evaluación grupal.

30 Roldán Barbero, op. cit., nota 10, p. 157. Es de tomarse muy en cuenta su siguiente reflexión: "Siempre es deseable el razonamiento lógico y el entendimiento jurídico, por supuesto. Sin embargo, la memoria cumplirá en todo momento un papel fundamental en el aprendizaje. Hay que procurar que los conocimientos memorizados no sean efímeros en razón de un estudio atolondrado y presuroso. En consecuencia, que ha de tomarse favorablemente en consideración a alumnos que, teniendo menos datos concretos, relacionan y exponen mejor, se les advierte perspicacia y profundidad jurídicas, y transmiten así la impresión, tan ansiada por todo profesor, de que los conocimientos manifestados perdurarán en su cultura jurídica internacional... debe inculcarse al alumno 'aprender a aprender' durante toda la vida". 
esto es, la capacidad de síntesis, la discriminación pensada de la información leída y recibida, y la consecuente distinción entre lo principal y lo secundario. A fin de cuentas, parafraseando al exquisito pedagogo Paulo Freyre: al estudiar no debemos pretender consumir ideas y conceptos, sino crearlos y recrearlos, para, en hermandad dialéctica, crear de nueva cuenta. 